\title{
球状上可䨢胞の 2 例
}

\section{笹倉裕一・笹倉真理・久米川一浩・新藤泗一}

\section{Two cases of globulomaxillary cyst}

\author{
Yuuichi Sasakura : Mari Sasaxura - Kazuhiro Kumzgawa Junichi Shindo
}

\begin{abstract}
This report presents two cases of globulomaxillary cyst at our hospital.
Case 1. This case was a 22 year old Japanese female who visited our hospital on February 18, 1982. She complained of unusual sensitivity in upper left side lateral incisor area. The upper left side lateral incisor with resin filling showed non-vital pulp, the upper left side canine was vital. Labial and palatal mucosa of their apical part showed no abnormal swelling nor redness, though the area was severely painful. The root distance between the upper left side lateral incisor and canine was expanded, as seen in radiograph. Using a local anesthesia, the cyst was surgically removed; part of the cyst wall contacted with the sinus mucosa. The cyst contained a light, yellow colored serous fluid.

Microscopic examination revealed cystic lining with stratified columner and cuboidal epithelium with scattered squamous epithelium. The wall of the cyst was infiltrated with chronic inflamatory cells. Case 2. A 50 year old Japanese male visited our hospital on October, 16, 1975. He complained of labial gingival swelling of upper left side, central and lateral incisor apical part. The upper left side central, lateral incisor and canine were vital. The cyst was the tip of thumb size, recognized clearly under the upper left side central and lateral incisor apical part in radiograph. Using a local anesthesia, the cyst was surgically removeed. The cyst contained yellow colored serous fluid. Microscopic examination revealed cystic lining with cuboidal epithelium. The loose connective tissue with few infiltrated cells was seen in subepithelial region. In addition to these two cases, we analyzed 62 cases in the existing Japanese literatures (1939-1983).
\end{abstract}

Key word: globulomaxillary cyst

暂高

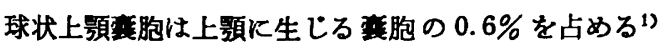
比較的まれな疾患である。本竞胞は胎生期における球状 突起と上䫑突起の空合部に残存した上皮より生ずる顔裂

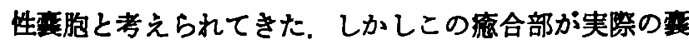
胞発生部位と一致しないことから，種々の議論がもたれ

神奈川歯科大学口㤏外科学教室

（主任：新藤㵎一教授）

Department of Oral and Maxillofacial Surgery, Kanagawa Dental College (Chief: Prof. Junichi Shindo)

受付日：昭和 60 年 9 月 24 日

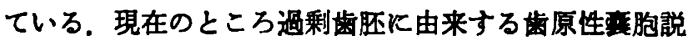
が有力の上5であるか，齿原性萣胞では割り切れない米 件る内蔵されている. 今回われわれは本症と考えられる 2 症例を経験したので報告する。

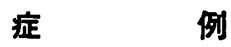

症例 $1: 22$ 歳 女性.

初 診：昭和 57 年 2 月回日。

主 訴：12遣和感.

現病歴：昭和 57 年 2 月， 9 年前にレジン充填した 12 に違和感を覚え開業歯科火受診。同部のデシタタX線撮 影飞て根尖部透過像を指摘され来院した。

家族歴・既往歴：特記すべき事員なし。 


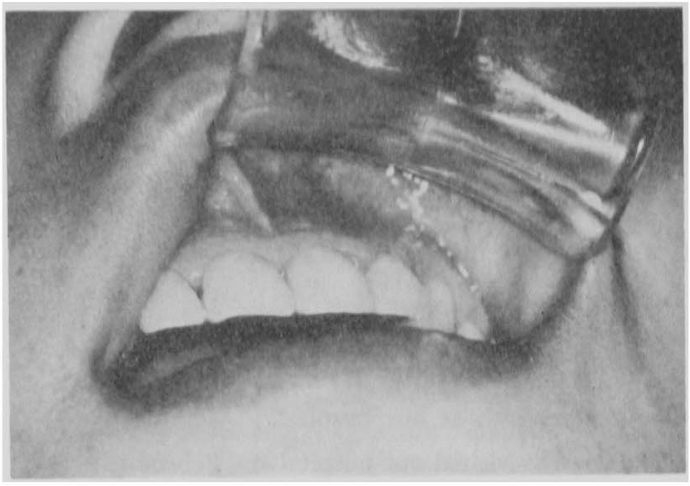

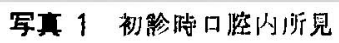

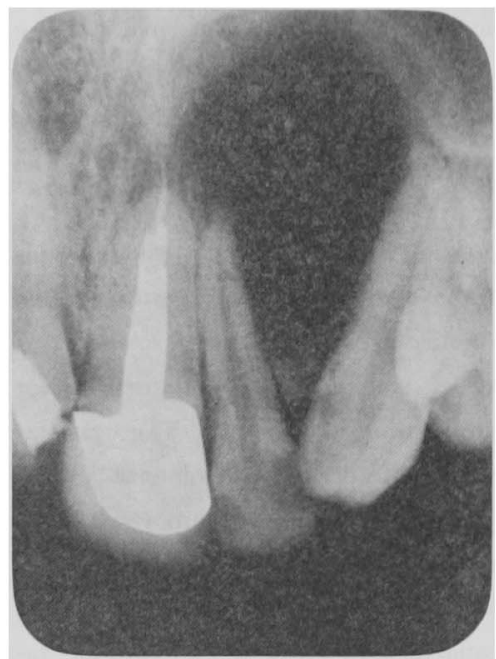

写真 2 初診時デンタルX線写真 所見

現 症：体格，栄養とも良好，顔貌正常，口腔内所見 では， 123 根尖部唇側歯肉に腫脹，発赤などはなかっ

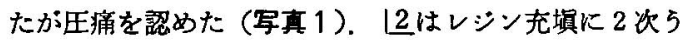

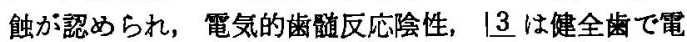
気的歯髄反応陽性であった。 X線所見では 233 根树 開があり，その間に境界明瞭な透過像が認められた（写 真 2 ).

初診時診断：球状上頻袈胞.

処置および経過：昭和57年 2 月口日局麻下にて億胞摘 出, および歯根端切除術を行った. 手術所見では, 粘獏 骨膜弁を豩離 したところ $\underline{23}$ 部唇側歯槽骨は菲薄化し 一部消失していた，豪胞壁は比較的平坦で周囲骨との癒 着はなく，上顎洞前壁の一部を吸収し上箩洞粘膜と接し ていたが别離は容易であった，内容液は淡黄色，芴液性 であった。

摘出物所見：衰胞壁は一部に出血斑が認められる色

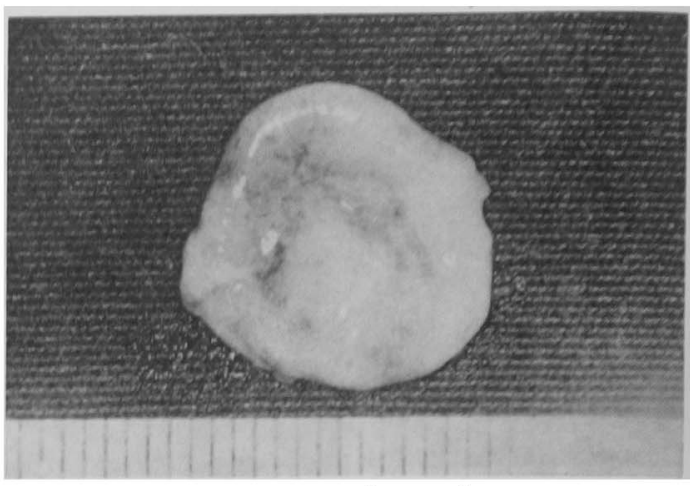

写西 3 摘出物纳眼所見

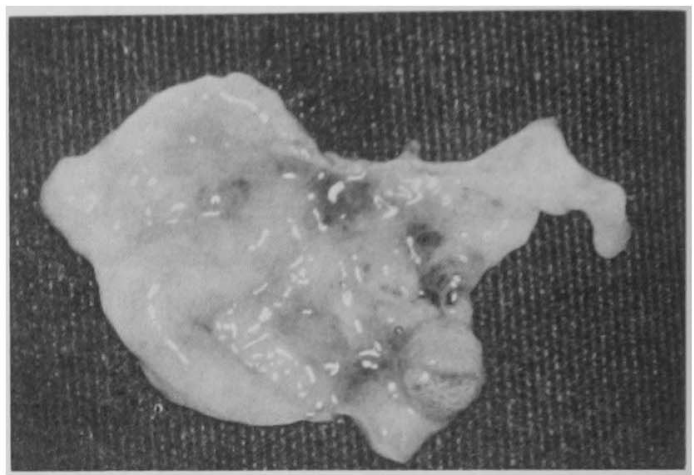

写真 4 摘出物割面肉眼所見

を呈し，滑沢で，武薄な部分と厚い部分が認められた (写开 3，4).

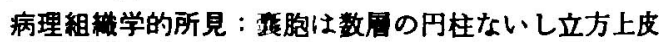
より成り，細胞間の空腺は広く，上皮下に細胞曼洞がみ られた（写重 5，6）.

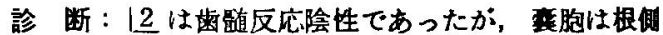
に深く侵入し，炎症の既往すなく，組織学的に円柱ない

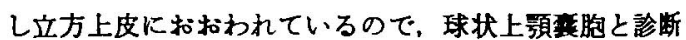
した.

症 例 $2: 54$ 歳 男性.

初診：昭和50年10月日日.

主 訴：左側上顎前歯部歯肉の隀脹。

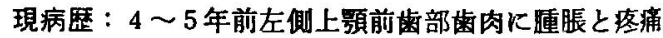

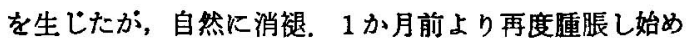
たので来院した。

現 症：12 齿肉唇移行部に弾性硬，軽い无痛を伴万

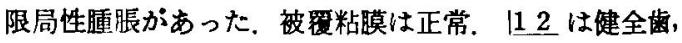

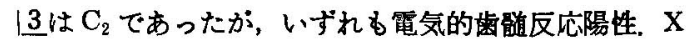
線所見では $1 \underline{12}$ 根尖部に拇指頭大の透過像を認めた (写真 7 ).

処置および程過：局麻下で粘膜骨膜升を利離したとこ 


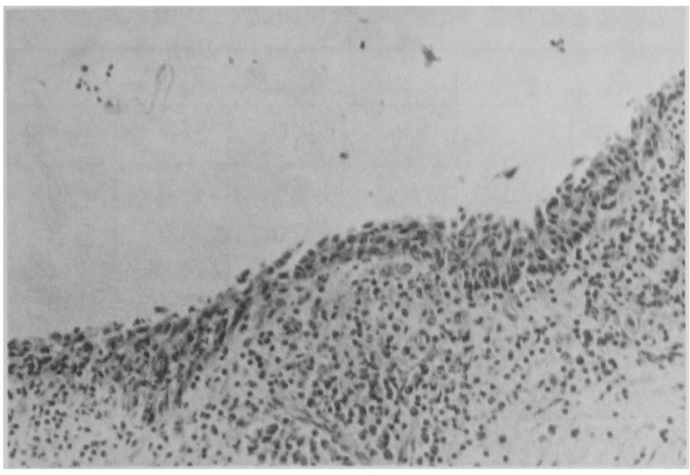

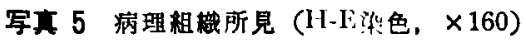

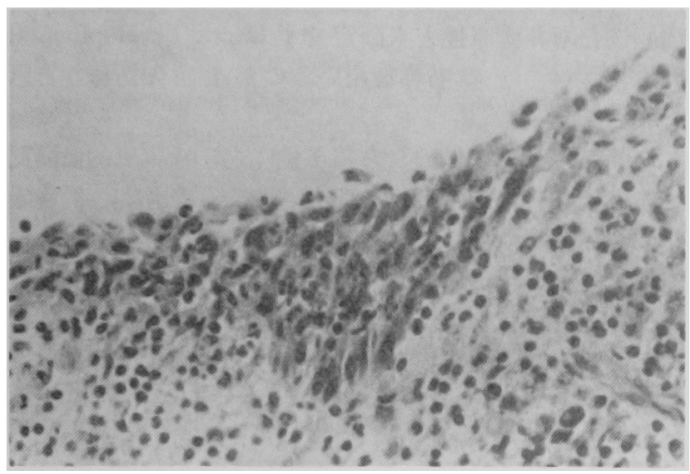

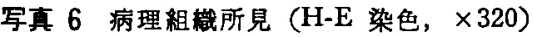

ろ，剅隆部に直径 $7 \mathrm{~mm}$ の骨吸収が認められた。焦胞壁 と切歯管とは骨によって隔てられていた，口蓋側歯槽骨 も一部吸収されていたが，绫着はなく，容易に剝離，摘 出し得た。内容液は黄色, 脽液性だった。

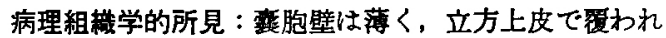
ており，上皮下は線維性組織のみで，細胞浸潤はほとん ど認められなかった（写真 8).

診 断：胞は 122 部根尖近くに存在していたが， いずれる生活齿で，組織学的にる立方上皮で覆われ，炎 症性細胞浸潤るほとんどないので，球状上䫑衰胞と診断 した.

\section{考察}

球状上顎素胞は Klestadt ${ }^{2)}$ 以来顔裂性莚胞といわれて きたが，近年その組織由来について種々の疑問が表明さ れている。まず Christ ${ }^{3)}$ は球状突起と上顎突起の瘜合部 が必ずしも上顎側奵霜と犬歯の間に一致しないのでこ

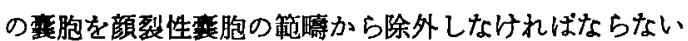
と述ぺている，そこで今回1939年から1983年の45年間に

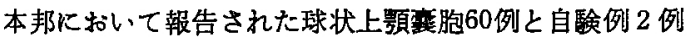

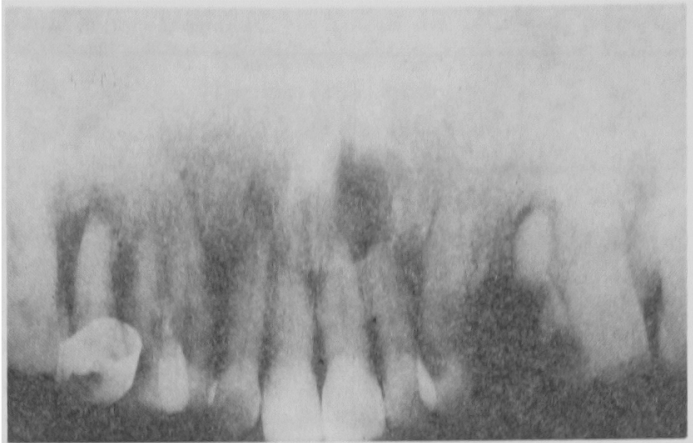

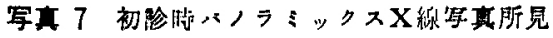

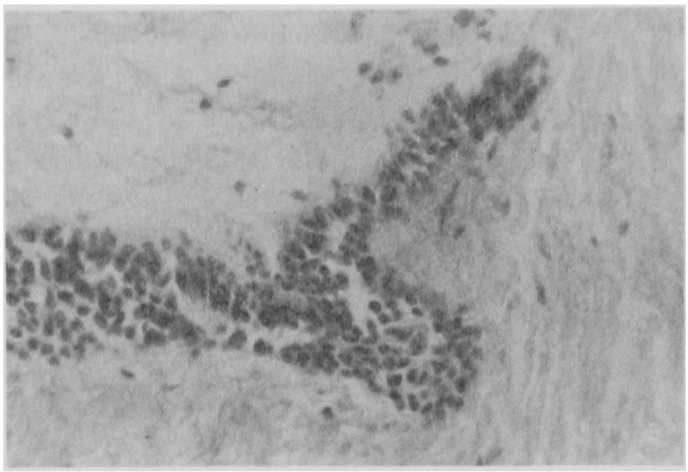

军吉 8 病理粗織所見 (H-E 染色， $\times 320)$

表 1 年龆および性別

\begin{tabular}{c|cc|c}
\hline 年龄 & 徏別 & 女 & 男 \\
\hline $10 \sim 19$ & 6 例 & 6 例 & 12 例 \\
$20 \sim 29$ & 12 & 11 & 23 \\
$30 \sim 39$ & 11 & 6 & 17 \\
$40 \sim$ & 6 & 3 & 9 \\
不 明 & & 1 & 1 \\
\hline 計 & 35 & 26 & 62 \\
\hline
\end{tabular}

について，主として唇顎口蓋裂4,5) と比較しながら考察 した．本疾患における男女比は 1.3:1 とやや男性に多 く，年跉は 20 藏代にもっとも多い(表 1).この点はあ まり特徽的ではないが，左右別にお゙いては本栾胞の発生 率は任ぽ 1:1であるのに対し，唇䫑口蓋裂では左側が 右側の約 2 倍の発生率となっている，発生部位では本雍 胞は上買側切歯之犬囷の間に70\%近く発生しており，少 数ではあるが上靧側切齿根尖部や，上顎中切歯と側切歯 の間に存在したケースる報告されている.これに対し㖽 裂では上䫓中切崡と側切歯の間に発生したるのが約半数 


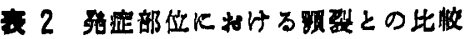

\begin{tabular}{|c|c|c|c|c|c|c|c|c|c|c|}
\hline \multirow{2}{*}{ 部位 } & \multirow{2}{*}{ 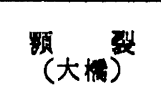 } & \multirow{2}{*}{ 球状上留 } & \multicolumn{4}{|c|}{ 胞上皮 } & \multicolumn{4}{|c|}{ 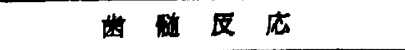 } \\
\hline & & & 円柱・立方 & 渄 合 & 平 & 不 明 & + & $+\cdot-$ & - & 不 明 \\
\hline 1123 & $100(50.3 \%)$ & $5(8.1 \%)$ & 0 & 3 & 1 & 1 & 4 & 1 & 0 & 0 \\
\hline $\begin{array}{l}1 / 3 \\
\quad 2 \\
\end{array}$ & - & $5(8.1)$ & 0 & 0 & 3 & 2 & 2 & 0 & 0 & 3 \\
\hline $12 \sqrt{3}$ & $12(6.0)$ & $42(67.6)$ & 6 & 5 & 20 & 11 & 14 & 6 & 4 & 18 \\
\hline その他 & $87(43.7)$ & $5(8.1)$ & 0 & 0 & 2 & 3 & 0 & 0 & 0 & 5 \\
\hline 不 明 & - & $5(8.1)$ & 1 & 0 & 1 & 3 & 0 & 0 & 0 & 5 \\
\hline 影 & $199(100)$ & $62(100)$ & 7 & 8 & 27 & 20 & 20 & 7 & 4 & 31 \\
\hline
\end{tabular}

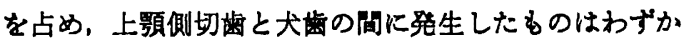

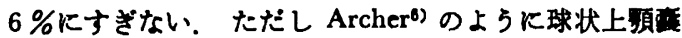
胞か上顠中切齿一側切歯間，側切歯一犬間，犬齿一第 1 小曰歯間に発生する可能性があるとしている人るある

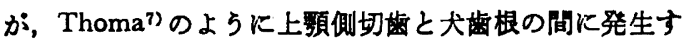
ることを本䯧胞の診断基渾としている人も多いので，側

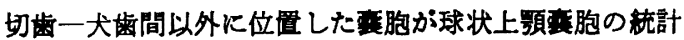
から除外されている可能性がある.いずれにしてる辰影 裂の発生部位と本宾胞の発生部位が一致しないことは事 実であり，顔裂性宾胞を否定する有力な根执となる，そ こで，本基胞の発生起原を別のところに求めるとすれ ば，歯原性烡胞であろらと思われるが，まず，齿根就胞 との鑑別についてみると，本变胞の発生部位と近接する 歯牙の電気的崡髄診断の記载があった 31 例のらち20例

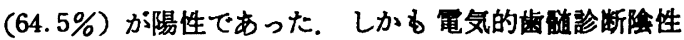
のなかでもら蝕の認められなかったすのもあり,これら の場合は本喜胞の発育による根尖の压迫などにより近接 する歯骮の失活を招いたとも十分に考えられる。次に過

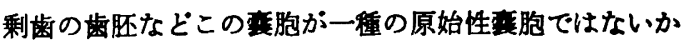

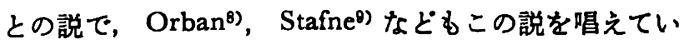
る. しかしこの部位は正中部と違って過剩雪の好発部位 ではないし，烡胞上皮の組織所見についてまとめてみる と，扁平上皮か： 27 例 (43.5\%) を占めてはいるか，円 柱・立方上皮が 7 例 (11.3\%), 円柱・立方上皮飞扁平 上皮が混在するるのを加えると15例 (24.2\%) Кなる.

一方, 球状上買熟胞と報告されたもののなかに角化上皮 は 1 例すなく，特に円柱ないし立方上皮を持った 15 例 (24.2\%) を原始性基胞とするのは難しい，北村 ${ }^{10)}$ は算 口蓋管の遺残や上顥洞上皮の迷入などを考えているが， 蓋管とは位置的にずれがあるし，上影洞粘膜と接し ているすのは自鍳例を含め 4 例にすぎなかった，本烡胞

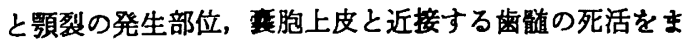
とめてみると，表2のよ5になり，本萁胞の起原を球状 突起と上額突起の㿑合時の遺残上皮に求めることる，歯 原性と断定することす困難と思われる。 しかしながらこ の部位に特定の条件を備えた衰胞が存在することは事実
なので，現在のところ Little'11)らのいらよらに本言胞を 齿原性とも非齔原性とる断定せず lateral developmental cyst of maxilla の名称を用いるのが妥当であろらと思 われる。

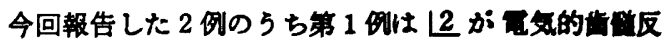

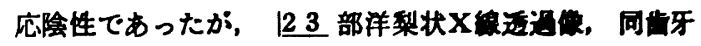

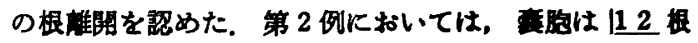

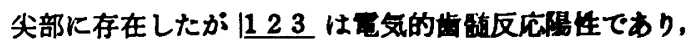
切齿管とは齔槽骨により境されていた，病理组篇学的に

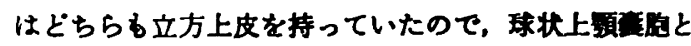
診断した.

以上考察したよ5K，われわれる本焦胸が球状咨起と 上䫑突起の䈍合部から発生するといら説に筆問を表明す るものであるが，本蓄胞がいまだ齿原性とる非齿原性と

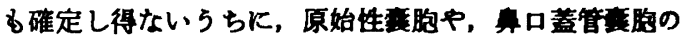
中に包含されてしま5のは，将来芜計的考察をする上て 非常に危険なことと考えて，従来の球状上顆算胞といら 名称を用いることにした。

\section{結籍}

22歳女性の左㑡側切歯，犬齿根間部，ならびマ54藏男 性の左側中，㑡切齿根尖部齿棈骨中下発生した球状上预 毫胞の 2 例を経検したので本邦報告例 (1939〜1983) 60

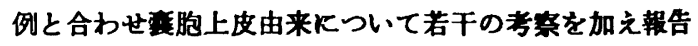
した。

本論文の要旨は第 129 回口貯外科学会関東地方会に発 表した。

\section{引用 文 献}

1) Hertz, J.: Globulomaxillary cyst invading the maxillary sinus. Report of two cases. OS OM OP 16: 392-396 1963.

2）石川梧朗：口腔病理学 II. 改訂肘, 永末書店, 
東京，1982，386-414頁より引用。

3) Chirst, T.F.: The globulomaxillary cyst. An embryologic misconception. Oral Surg 30: 515-526 1970.

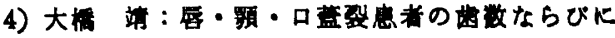

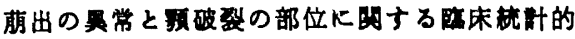
研究. 口科誌 13：401-422 1964.

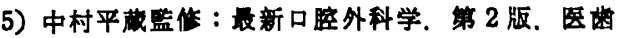
萖出版, 東京, 1975，755-763頁。

6) Archer, W.H.: Oral and Maxillofacial Surgery. 1 Ed 5, Saunders Co, Philadelphia, 1975, p 522.

7) Thoma, K.H.: Facial cleft or fissual cysts. Int J Orthod \& Oral Surg 23: 83-89 1937.

8) Orban: Orban's Oral Histology and Embryology. 9 th Ed, Mosby Co, St Louis, 1980, p 22.

9) Stafne, E.C. and Gibilisco, J.A.: Oral Roentgenographic Diagnosis. 4 Ed, Saunders Co, Phiradelphia, 1975, p 164.

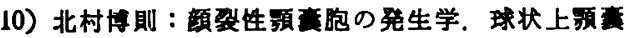
胞の道采起原の可能性. 神奈川齿学 11：1211976.

11) Little, J.W. and Jakobsen, J.: Origin of the globulomaxillary cyst. J Oral Surg 31: 1881951973.

12) 梗本昭二, 岩佐俊明, 他 : 原始性严胞 (primordial cyst) の度床的研究. 日口外誌 23: 1211281977.

13）高木圭二郎：顔面破裂要隀の一型たる球状上影 整胞と信ずでき稀有なる一例，大日本迷誌 36 : 377-385 1939.

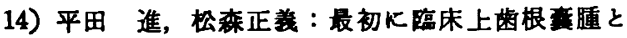
思われ手政後に非歯性球状上影售腫なりと確め られたる稀有なる一例. 度応菌科医学 1: 227 1941.

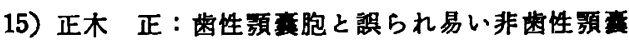

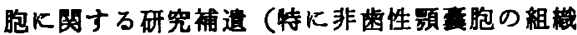
像と其発生機枟に就て)。旲本誌 37：2592981941.

16）前川重和，藤原忠行：巨大なる球状上顥索腫の 稀有なる一例. 大日本歯誌 38: 293-304 1941.

17）石田孝雄：左右两㑡に対称性に発現した球状上 額毫胞に就て。歯科学報 48: 252-259 1942.

18）明楽和雄，北村実雄：球状上额菱胞の 1 例. 海 科学報, 51：205-209 1951.

19）高橋瑐一, 太田喜一郎：球状上顎菱胞の 1 例. 口科誌 1：299-302 1952.

20）大木茂雄，新藤勝己：対称性に発生した球状上 額咅胞と考えられる一症例について，齿学 42: 57-62 1954.

21）鉿木美政，鈴木義三郎，他：監床上稀にみる球 状上顥毫胞の一例. 畨科学報 55: 115-118 1955.

22）新井俊二, 迁 正, 他 : 球状上頻咅胞の 1 例

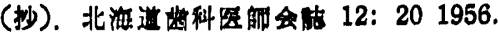

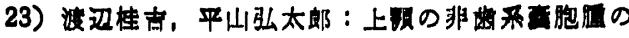
3 症例。 耳喉 30: 1065-1068 1958.

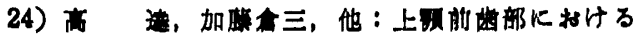

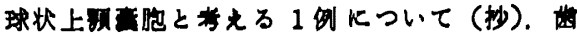
科学郝 59: 251-252 1959.

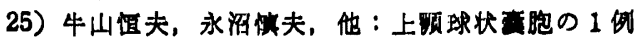
(抄)。科月制 32: 131961 。

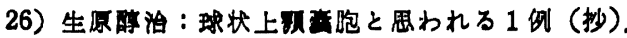
北道科医啲会䀦 17：50-52 1964.

27) 中山栄婎，和田但宏，他：具味むるレ線像を示

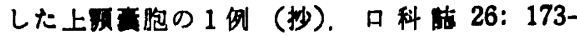
1741976.

28）浜田意球状上周表胞と思われる1例につい て. 日本科㤘㖮 291: 101-102 1967.

29）北山䁍二，広瀬恒久，他：球状上顆蓝胞の 1 例. 爱院大誌 5: 250-253 1967 .

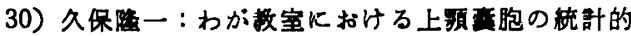

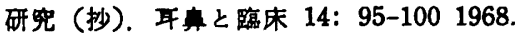

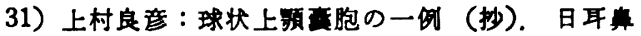
70: 21581967.

32）柏原利子，郡司伊等夫：球状上颛责胞の一应例 (抄)。目耳 74：1516 1971 .

33）谷口幸治, 土井尚，他：球状上穎咅胞の 1 例. 口科就 20：856-859 1971.

34）柴田宽一：䫫骨内に発生した先天性落胞の应例 (抄). 日耳年 75: 1347-1348 1972.

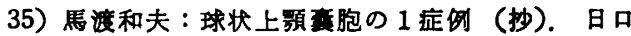
外誌 19: 1051973.

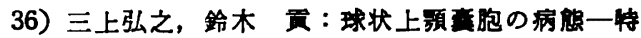
K，その臨床所見と内容液の性状火ついて一 （抄）。旦外誌 21：665-666 1975.

37）水谷英守，小畑研一，他：顔裂性落胞の 2 例 (抄). 日口外誌 22: 1381976.

38）洗谷孝順，長崎昭男，他：两側性に発生した球 状上影㧤胞の 1 例 (抄). 日口外誌 22: 164 1976.

39）山本悦香，佐藤健夫，他：算腔領城に進展した 球状上䫑咅胞の 2 例。病誌 43：173-178 1976.

40）石田 惠, 江口和子, 他 : 顏裂性虽胞64例の臨

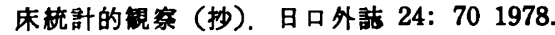

41）関保傹川富男，他：球状上颖言胞の 2 侧 (抄). 日外誌 24: 70-71 1978 .

42）金田多恵子, 福田云一, 他：球状上顥烡胞の 1 症例。 日外誌 25：146-151 1979.

43）宮竹 昭，末厷 実，他：Globulomaxillary cyst と思われる巨大な上影蕉胞の 1 症例 (抄). 日耳鼻 81：414 1978 .

44）吉田赛治，向井則介，他：上額两側に発生した 2 つの大きな真胞に対する 1 手街法(抄). 齿学 66: 405-406 1978.

45）坂本伸雄, 海野徳二, 他 : Globulomaxillary cyst の 2 症例 (抄). 日耳帮 81: 14861978.

46) 增田 屯, 町野 守, 他: 顔裂性京胞の 2 例. 
城粑大婹 8: 121-127 1979.

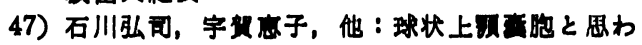
れる 1 症例 (抄). 海学 67: 222-223 1979.

48）高松英世, 前田使一郎，他：球状上鄂素胞の 1 例（抄）。日口外誌 26: 247-248 1980 .

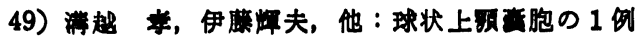

(抄). 日斥佶 26: 5121980 。

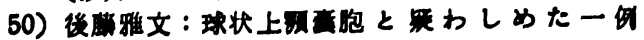
（抄）。防街得生 27：238-239 1980.

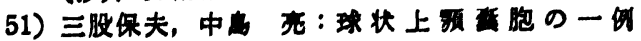

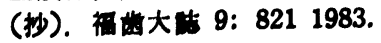

